\title{
Validation of publication of new names and new combinations previously effectively published outside the IJSB - Validation List no. 68
}

International Journal of Systematic Bacteriology (1999), 49, 1-3

p. 2, the nomenclatural type (type strain) of Psychroflexus gondwanensis is 'ACAM 44' not 'ACAM 48' as given in the original effective publication

\section{Erwinia pyrifoliae sp. nov., a novel pathogen that affects Asian pear trees (Pyrus pyrifolia Nakai)}

Won-Sik Kim, Louis Gardan, Seong-Lyul Rhim and Klaus Geider

International Journal of Systematic Bacteriology (1999), 49, 899-906

Owing to a printing error the final pagc of the paper was blank. The omitted text is reproduced below.

Rhim, 5.-L., Völksch, B., Gardan, L., Paulin, J.-P., Langlotz, C., Kim, W.-S. \& Geider, K. (1999). Erwinia pyrifoliae, an Erwinia species different from Erwinia amylovora, causes a necrotic disease of Asian pear trees. Plant Pathol (in press).

Saitou, N. \& Nei, M. (1987). The neighbor-joining method: a new method for reconstructing phylogenetic trees. Mol Biol Evol 4, 406-425.

Schroth, M. N. \& Hildebrand, D. C. (1988). Amylovora or nonsoftrot group. In Laboratory Guide to Identification of Plant Pathogenic Bacteria, 2nd edn. Edited by N. W. Schaad. St Paul, $\mathrm{MN}$ : American Phytopathological Society.

Smibert, M. R. \& Krieg, N. R. (1981). General characterization. In Manual of Methods for General Microbiology, pp. 409-443. Washington, DC: American Society for Microbiology.
Sneath, P. H. A. \& Sokal, R. R. (1973). Numerical Taxonomy. The Principles and Practice of Numerical Classification. San Francisco: Freeman.

Weisburg, W. G., Barns, S. M., Pelletier, D. A. \& Lane, D. J. (1991). 16S ribosomal DNA amplification for phylogenetic study. $J$ Bacteriol 173, 697-703.

Young, J. M., Saddler, G. S., Takikawa, Y., de Boer, S. H., Vauterin, L., Gardan, L., Gvozdyak, R. I. \& Stead, D. E. (1996). Names of plant pathogenic bacteria 1864-1995. Rev Plant Pathol 9, $721-762$.

Zavaleta, A. I., Martínez-Murcia, A. J. \& Rodríguez-Valera, F. (1996). 16S-23S rRNA intergenic sequence indicate that Leuconostoc oenos is phylogenetically homogeneous. Microbiology 142, 2105-2114.

\section{Validation of publication of new names and new combinations previously effectively published outside the IJSB - Validation List no. 70}

International Journal of Systematic Bacteriology (1999), 49, 935-936

p. 935, the nomenclatural type (type strain) of Sphingomonas suberifaciens is 'ATCC 49355' not 'ATCC 49382' as given in the original effective publication

\section{Cryptobacterium curtum gen. nov., sp. nov., a new genus of Gram-positive anaerobic rod isolated from human oral cavities}

Futoshi Nakazawa, Sergio E. Poco, Tetsuro Ikeda, Michiko Sato, Sotos Kalfas, Göran Sundqvist and Etsuro Hoshino International Journal of Systematic Bacteriology (1999), 49, 1193-1200

pp. 1195 (Fig.1 legend), 1198 (Fig. 3 legend) and 1199, the collection number for the type strain of Cryptobacterium curtum is 'ATCC 700683 ' not 'ATCC 700863 ' 